\title{
EVALUASI PROGRAM KECAKAPAN HIDUP BAGI WARGA BINAAN DI LEMBAGA PEMASYARAKATAN ANAK KELAS IIA KUTOARJO
}

\section{AN EVALUATION OF THE LIFE SKILLS PROGRAM FOR PRISONERS IN CHILDREN'S CORRECTIONAL CENTER IIA KUTOARJO}

\author{
Tristanti, Yoyon Suryono \\ Universitas Negeri Yogyakarta, Universitas Negeri Yogyakarta \\ Triest_casa@yahoo.co.id, yoyonsuryono@yahoo.com
}

\begin{abstract}
Abstrak
Penelitian ini bertujuan mengetahui pelaksanaan, keberhasilan dan kendala-kendala program kecakapan hidup bagi warga binaan di Lembaga Pemasyarakatan Anak (LPA) Kelas IIA Kutoarjo. Penelitian ini merupakan penelitian evaluasi dengan menggunakan model penelitian CIPP. Pengumpulan data menggunakan metode wawancara, dokumentasi, dan observasi. Hasil penelitian menunjukkan pelaksanaan program pada aspek konteks menunjukkan kesesuaian antara kebutuhan dan partisipasi warga belajar, pengalaman warga belajar dan kondisi lingkungan dengan kegiatan program. Pada aspek masukan menunjukkan motivasi warga belajar, karakteristik warga belajar, karakteristik narasumber, pendanaan, dan sarana prasarana dalam kategori baik. Aspek proses menunjukkan aktifitas warga belajar, strategi pembelajaran dan hubungan antar pribadi dalam kategori baik. Aspek hasil menunjukkan semua kegiatan keterampilan dapat terlaksana dengan baik. Keberhasilan program keterampilan ditunjukkan oleh perubahan perilaku warga belajar yang meliputi kecakapan tangan, kecakapan hati, kecakapan otak dan kecakapan sehat.
\end{abstract}

Kata kunci: Pelaksanaan program kecakapan hidup, keberhasilan program kecakapan hidup

\begin{abstract}
This study aims to investigate the implementation, the attainment of the success of the program, and the constraints of the program for the prisoners in Children's Correctional Center Class IIA Kutoarjo. This was an evaluation study employing the CIPP. The data were collected through interviews, documentation, and observations. The context aspect shows relevance among the learners' needs and participation, their learning experiences and the environmental condition, and the program activities. The input aspect shows that the learners' motivation and characteristics, the tutors' characteristics, the funding, and the infrastructure facilities are good.The process aspect shows that the learners' activities, the learning strategies, and the interpersonal relationship are good.The product aspect shows that all the skills activities can be well implemented. The success of the skills program is indicated by changes in the learners' attitudes manifested in the manual skill, spiritual skill, intellectual skill, and health skill are good.
\end{abstract}

Keywords: Implementation of skills program, success of skills program 


\section{PENDAHULUAN}

Pesatnya kemajuan teknologi menjadikan kehidupan masyarakat semakin modern. Kehidupan anak-anak sangat rentan terpengaruh oleh perkembangan tersebut, sehingga mengakibatkan anak-anak menjalani perbuatan kriminal atau kejahatan.

Anak-anak yang melakukan tindakan kejahatan atau kriminal akan diproses secara hukum sesuai undang-undang yang berlaku. Mereka yang bersalah akan ditempatkan di LPA untuk mendapat pembinaan atau rehabilitasi. Salah satu LPA yang melakukan pembinaan yaitu Lembaga Pemasyarakatan Anak Kelas IIA Kutoarjo.

Pengaturan pemasyarakatan tercantum dalam Undang-Undang No. 12 Tahun 1995. Menurut Undang-Undang No.12 Tahun 1995 tentang pemasyarakatan, Pasal I angka 1 memaparkan tentang definisi pemasyarakatan yaitu kegiatan untuk melakukan pembinaan warga binaan pemasyarakatan berdasarkan sisitem, kelembagaan, dan cara pembinaan yang merupakan bagian akhir dari sistem pemidanaan dalam tata peradilan pidana. Jadi pemasyarakatan memunyai makna pembinaan terhadap narapidana supaya nantinya dapat kembali ke masyarakat. Pembinaan itu dapat berjalan dengan baik apabila didukung oleh suatu sistem yang dinamakan pemasyarakatan.

Lembaga Pemasyarakatan sebagai ujung tombak bagi pelaksanaan UndangUndang No.12 tahun 1995, juga merupakan tempat untuk mencapai tujuan tersebut di atas. Lembaga Pemasyarakatan mengadakan kegiatan-kegiatan Pembinaan, Rehabilitasi dan Reintegrasi. Sejalan dengan peran Lembaga Pemasyarakatan tersebut maka tepatlah bila Petugas Pemasyarakatan yang melaksanakan tugas-tugas pembinaan bagi warga binaan pemasyarakatan ditetapkan sebagai Pejabat fungsional penegak hukum. Pejabat fungsional penegak hukum memunyai kewajiban atas terselenggaranya kegiatan-kegiatan pembinaan, rehabilitasi dan reintegrasi di Lembaga Pemasyarakatan.

Menurut pasal 1 angka 2 UndangUndang No.12 Tahun 1995 tentang Pemasyarakatan menyebutkan bahwa sistem pemasyarakatan adalah suatu tatanan mengenai arah dan batas serta cara pembinaan warga binaan pemasyarakatan berdasarkan Pancasila yang dilaksanakan secara terpadu antara Pembina, yang dibina, dan masyarakat untuk meningkatkan kualitas warga binaan pemasyarakatan agar menyadari kesalahan, memerbaiki diri, dan tidak mengulangi tindak pidana sehingga dapat diterima kembali oleh lingkungan masyarakat, dapat aktif berperan dalam pembangunan, dan dapat hidup secara wajar sebagai warga yang baik dan bertanggung jawab. Pembinaan terhadap warga binaan pemasyarakatan dilakukan di Lembaga Pemasyarakatan. Pembinaan yang dilaksanakan di Lembaga Pemasyarakatan harus didasarkan pada suatu asas yang harus dipegang oleh para Pembina agar dapat tercapai tujuan dan pembinaan itu sendiri. Dalam Pasal 5 Undang-Undang No.12 tahun 1995 tentang Pemasyarakatan, disebutkan 7 asas sistem pembinaan pemasyarakatan, yaitu: (a) Pengayoman; (b) Persamaan perlakuan dan pelayanan Pendidikan; (c) Pembimbingan; (d) Penghormatan harkat dan martabat manusia; (e) Kehilangan kemerdekaan merupakan satusatunya penderitaan; (f) Terjaminnya hak untuk tetap berhubungan dengan keluarga dan orang-orang tertentu.

Di LPA Kutoarjo anak-anak akan mendapatkan pembinaan dan rehabilitasi.

Perlindungan Sosial diberikan kepada anak-anak yang berhadapan dengan hukum, untuk menjamin pemenuhan hak anak untuk hidup, tumbuh kembang dan berpartisipasi, serta melindungi anak dari diskriminasi, tindak kekerasan, eksploitasi dan penelantaran. Adapun rehabilitasi sosial diberikan kepada Anak Berhadapan Hukum $(\mathrm{ABH})$, untuk dapat mengembalikan serta mengembangkan keberfungsian sosial anak, melalui berbagai program pengubahan perilaku, serta program-program sosial lainnya yang bisa mempermudah anak melalui proses reintegrasi sosial dengan lingkungan sosialnya, setelah anak selesai menjalani masa putusan pengadilan atau selesai melalui program peradilan restoratif yang berbasis masyarakat. Proses perlindungan dan rehabilitasi sosial diberikan kepada anakanak yang berhadapan dengan hukum, baik dalam proses peradilan formal maupun da- 
lam proses penyelesaian kasus dengan pendekatan peradilan restoratif (informal). Program perlindungan dan rehabilitasi sosial dalam proses informal, dimulai dari penyelenggaraan berbagai program pencegahan kepada anak-anak yang ada dalam situasi rentan untuk terlibat dalam konflik hukum. Bagi anak-anak yang sudah berhadapan dengan hukum, berbagai upaya dilakukan untuk terselenggaranya musyawarah (keluarga dan masyarakat) sebagai wahana penyelesaian kasus anak tanpa melalui proses peradilan formal.

Sebagai sarana rehabilitasi sosial dan pengubahan perilaku anak di dalam masyarakat, maka perlu difasilitasi berbagai program dukungan sosial bagi anak pascamusyawarah. Selain itu, pemberian pendampingan psikososial bagi anak dan keluarganya juga perlu dilakukan untuk membantu anak dan keluarga tersebut mengatasi permasalahan-permasalahan psikososial berkaitan dengan keterlibatannya dalam konflik hukum yang mereka hadapi. Untuk menjamin agar anak dan keluarga benarbenar menjalankan kesepakatan yang telah dihasilkan pada musyawarah (keluarga atau masyarakat) maka upaya pengawasan pun harus dilakukan dengan melibatkan tokoh atau warga masyarakat setempat. Lebih dari itu, berbagai program rehabilitasi dan reintegrasi sosial harus diciptakan dan diselenggarakan agar bisa diakses oleh anakanak yang akan dikembalikan kepada keluarga dan masyarakatnya.

Proses perlindungan dan rehabilitasi sosial bagi $\mathrm{ABH}$ yang telah masuk dalam poses peradilan formal dilaksanakan mulai dari proses pelaporan kasus ke polisi, pada tahap penyidikan, penuntutan dan persidangan, masa manjalankan tindakan, bahkan ketika anak berada di dalam lembaga pemasyarakatan, sampai dengan masa pembebasan. Ketika, peradilan restoratif tidak bisa dilaksanakan karena satu dan lain hal, maka proses peradilan formal perlu diupayakan dengan tetap memberikan jaminan bagi pemenuhan hak-hak dasar anak yang ditunjang dengan pemberian pelayanan sosial dasar bagi anak dengan perpertimbangan kepentingan terbaik anak, serta dengan tetap memperhatikan dan meng- utamakan hak anak atas pengasuhan orang tua.

Upaya-upaya diversi perlu dilakukan pada setiap tahapan proses peradilan formal, sebagai perwujudan dari pengutamaan pengasuhan anak dalam lingkungan keluarga. Secara ringkas dalam Petunjuk teknis Kementrian Sosial RI Tahun 2011 dapat dijelaskan bahwa program perlindungan dan rehabilitasi sosial anak yang berhadapan dengan hukum meliputi 4 (empat) aspek, yaitu: pencegahan, perlindungan, pelayanan dan pengasuhan.

Perlunya pembinaan yang bersifat rehabilitasi dikarenakan mereka sedang dalam masa remaja. Menurut Erikson (Kartono, 1992, p.9) secara umum remaja dianggap ada dalam satu periode transisi dengan tingkah laku anti-sosial yang potensial, disertai dengan banyak pergolakan hati atau kekisruhan batin pada fase-fase remaja. Maka segala gejala kejahatan yang muncul itu merupakan akibat dari proses perkembangan pribadi anak yang mengandung unsur dan usaha: (a) Kedewasaan seksual; (b) Pencarian suatu identitas kedewasaan; (c) Adanya ambisi materiil yang tidak terkendali; (d) Kurang atau tidak adanya disiplin diri.

Ciri-ciri khusus pada remaja menurut Hurlock (Izzaty dkk, 2008, pp.124-126) adalah: (a) Masa remaja sebagai periode penting karena akibatnya yang langsung terhadap sikap dan perilaku dan akibat jangka panjangnya, juga akibat fisik dan akibat psikologis. Perkembangan fisik yang cepat dan penting disertai dengan cepatnya perkembangan mental yang cepat menimbulkan penyesuaian mental dan membentuk sikap, nilai dan minat baru; (b) Masa remaja sebagai periode peralihan, masa remaja merupakan peralihan dari masa kanak-kanak ke masa dewasa, sehingga mereka harus meninggalkan segala sesuatu yang bersifat kekanak-kanakan serta mempelajari pola perilaku dan sikap baru untuk menggantikan perilaku dan sikap yang sudah ditinggalkan. Pada masa ini remaja bukan lagi seorang anak dan juga bukan orang dewasa; (c) Masa remaja sebagai periode perubahan, selama remaja terjadi perubahan fisik yang sangat pesat, juga perubahan perilaku dan 
sikap yang berlangsung pesat. Menurut Hurlock, ada 4 macam perubahan yaitu: meningginya emosi, perubahan tubuh, minat dan peran yang diharapkan, berubahnya minat dan pola perilaku serta adanya sikap ambivalen terhadap setiap perubahan; (d) Masa remaja sebagai masa mencari identitas, pada masa ini mereka mulai mendambakan identitas diri dan tidak puas lagi dengan menjadi sama dengan teman-teman dalam segala hal, seperti pada masa sebelumnya. Namun adanya sifat yang mendua, dalam beberapa kasus menimbulkan suatu dilemma yang menyebabkan krisis identitas. Pada saat ini remaja berusaha untuk menunjukkan siapa diri dan peranannya dalam kehidupan masyarakat; (f) Usia bermasalah, karena pada masa remaja pemecahan masalah sudah tidak seperti pada masa sebelumnya yang dibantu oleh orang tua dan gurunya; (g) Masa remaja sebagai usia yang menimbulkan ketakutan/kesulitan, karena pada masa remaja sering timbul pandangan yang kurang baik atau bersifat negatif. Stereotip demikian mempengaruhi konsep diri dan sikap remaja terhadap dirinya, dengan demikian menjadikan remaja sulit melakukan peralihan menuju dewasa; (h) Masa remaja sebagai masa yang tidak realistik. Pada masa ini remaja cenderung memandang dirinya dan orang lain sebagaimana yang didinginkan bukan sebagaimana adanya, lebih-lebih cita-citanya. Hal ini menyebabkan emosi meninggi dan apabila yang didinginkan tidak tercapai akan mudah marah. Semakin bertambahnya pengalaman pribadi dan sosialnya serta kemampuan berfikir rasional remaja memandang diri dan orang lain semakin realistik; (i) Masa remaja sebagai ambang masa dewasa. Menjelang menginjak masa dewasa mereka merasa gelisah untuk meninggalkan masa belasan tahunnya. Mereka belum cukup untuk berperilaku sebagai orang dewasa, oleh karena itu mereka berperilaku sebagai status orang dewasa seperti cara berpakaian, merokok, menggunakan obat-obatan, dll yang dipandang memberikan citra seperti yang didinginkan. Dari pengertian remaja di atas dapat disimpulkan bahwa remaja adalah masa di mana seorang anak mulai nenentukan arah kehidupannya yang ditandai dengan berbagai karakteristik seperti terjadinya perubahan fisik, berperilaku seperti orang dewasa dan mulai meninggalkan masa kekanak-kanakannya. Usia remaja adalah usia yang rawan karena masa ini mereka berusaha mencari jati dirinya. Oleh karenanya perlu bimbingan yang kuat agar remaja tidak salah dalam bertindak.

Lingkungan sosial dan budaya yang tidak positif merupakan faktor risiko bagi remaja untuk terjebak dalam perilaku yang membahayakan kesehatan dan keselamatan remaja. Perilaku tersebut antara lain merokok, penggunaan narkoba atau minuman keras, seks sebelum menikah, tawuran, perilaku kriminal, atau bunuh diri.

Dalam masa remaja yang begitu rawan dan penuh risiko, remaja perlu dibekali dasar untuk perkembangan jiwa yang sehat. Kondisi kesehatan jiwa yang baik amat diperlukan agar remaja mampu melewati masa transisinya dan dapat mencapai kedewasaan tanpa masalah yang berarti.

Pembinaan yang diberikan salah satunya melalui program kecakapan hidup. Kecakapan hidup yang ada di sana yaitu keterampilan perkebunan, peternakan dan pembuatan sandal. Tujuan kegiatan keterampilan selama ini adalah untuk memberikan pelatihan kerja bagi warga binaan. Penanaman sikap-sikap positif juga selalu diberikan bagi warga binaan. Hal ini dikarenakan pendidikan kecakapan hidup pada dasarnya tidak hanya sebagai pemberian bekal bagi warga binaan untuk menjamin kelangsungan hidupnya nanti. Kecakapan vokasional saja tidak akan cukup membuat anak menjadi pribadi yang lebih baik dari sebelumnya. Menurut Satori (Anwar, 2002, p.20) istilah hidup dalam istilah kecakapan hidup tidak semata-mata memiliki kemampuan tertentu saja (vocational job), namun harus memiliki kemampuan dasar pendukungnya secara fungsional seperti membaca, menulis, menghitung, merumuskan dan memecahkan masalah mengelola sumber daya, bekerja dalam tim, terus belajar di tempat kerja, mempergunakan teknologi. Kamil (2010, p.131) mengatakan bahwa kecakapan hidup adalah peningkatan kemampuan dan keterampilan yang memberi bekal dasar dan latihan yang dilakukan secara 
benar kepada masyarakat (peserta) tentang nilai-nilai kehidupan sehari-hari agar yang bersangkutan mampu, sanggup, dan terampil menjalankan kehidupannya yaitu dapat menjaga kelangsungan hidup dan perkembangannya.

Menurut Satori (Anwar, 2006, p.21) cakupan kecakapan hidup sangat luas seperti kecakapan berkomunikasi, kecakapan membuat keputusan, kecakapan memanajemen waktu dan sumber daya dan kecakapan perencanaan. Pengembangan kecakapan hidup pada umumnya bersumber pada kajian dunia kerja, keterampilan hidup praktis, pengelolaan individu dan manajemen dan keterampilan sosial.

Berbeda dengan pendapat Brolin (Suryono, 2010, p.11) menyatakan kecakapan hidup mencakup kecakapan hidup sehari-hari (daily living skill) seperti pengelolaan kebutuhan pribadi, pengelolaan keuangan pribadi, dan pengelolaan waktu luang dan rekreasi, kecakapan hidup pribadi/sosial seperti kesadaran diri, percaya diri, tenggang rasa pada sesama dan mengembangkan kebiasaan positif, dan kecakapan hidup bekerja (occupational skill) seperti kecakapan memilih pekerjaan, perencanaan kerja, persiapan keterampilan kerja, penguasaan keterampilan kerja dan penerapan teknologi.

Pendidikan kecakapan hidup (life skills education) merupakan pendidikan bagi anak usia sekolah untuk meningkatkan kompetensi psikososialnya. Kecakapan hidup tersebut termasuk kemampuan menyelesaikan masalah, berpikir kritis, berkomunikasi dan membentuk hubungan interpersonal, empati, dan metode untuk menghadapi emosi. Dengan kemampuan ini anak dan remaja dapat berkembang mencapai derajat kesehatan jiwa yang positif dan tangguh. Sedangkan Francis (2007, p.1) menyatakan bahwa kecakapan hidup meliputi cakupan kepemimpinan, etika, akuntabilitas, kemampuan adaptif, produktivitas personal, tanggung jawab personal, dan terhadap orang lain dan pengarahan diri sendiri. Kecakapan kepemimpinan memungkinkan seseorang mengatasi masalah, mencapai tujuan hidupnya dan kemampuan untuk memotivasi orang lain dan juga ke- mampuan mencapai tujuan bersama. Individu bermaksud mencapai standar pencapaian yang tinggi dengan mengikuti etikaetika pada dirinya dan kehidupan profesionalnya. Individu akan dapat beradaptsi pada perbedaan peran dan tanggung jawab. Individu-individu dapat bertoleransi pada 'ambiguitas' dan berkeinginan mengubah prioritas mereka sebagaimana dibutuhkan. Jadi mereka berkomitmen terhadap pekerjaannya dengan menggunakan waktu lebih efektif. Terkait dengan kecakapan hidup tersebut, pendidikan kecakapan hidup akan efektif jika orang-orang dapat bertindak mendasarkan pada kecakapan yang mereka pelajari, menjadi landasan dasar untuk memelajari keahlian lebih dalam yang dibutuhkan pasar, memungkinkan individu dapat mengarahkan dirinya, memantau pemahaman (www.changingminds.org).

Tujuan kecakapan hidup menurut Kamil (2010, p.131) dijelaskan dalam lima tujuan yaitu: (1) memberdayakan asset kualitas batiniyah, sikap dan perbuatan lahiriah peserta masyarakat melalui pengenalan (logos), penghayatan (etos) dan pengamalan (patos) nilai-nilai kehidupan sehari-hari sehingga dapat digunakan untuk menjaga kelangsungan hidup dan perkembangannya. (2) memberikan wawasan yang luas tentang pengembangan karir yang dimulai dari pengenalan diri, eksplorasi karir, orientasi karir dan penyiapan karir. (3) memberikan bekal dasar dan latihan-latihan yang dilakukan secara benar mengenai nilai-nilai kehidupan sehari-hari yang dapat memampukan masyarakat untuk berfungsi menghadapi kehidupan masa depan yang sarat kompetensi dan kolaborasi sekaligus. (4) mengoptimalkan pemanfaatan sumber daya melalui masyarakat melalui pendekatan manajemen pembangunan dengan mendorong peningkatan kemandirian, partisipasi, dan fleksibilitas pengelolaan sumber daya masyarakat. (5) memfasilitasi masyarakat dalam memecahkan permasalahan kehidupan yang dihadapi sehari-hari.

Menurut Sumarno (Suryono dkk, 2010, p.14) tujuan program kecakapan hidup adalah ditinjau dari dua perspektif yaitu dari kualitas individu dan kualitas agregatif. Pada perspektif kualitas individu berarti 
program pendidikan kecakapan hidup mampu menjadikan setiap peserta didik memiliki keterampilan yang dibutuhkan oleh dirinya dan masyarakatnya. Sedangkan perspektif agregatif berarti keluaran pendidikan kecakapan hidup dituntut memiliki komposisi keahlian yang sesuai dengan arah perubahan lingkungan masyarakatnya.

Oleh karena itu, LPA dihadapkan pada tantangan besar yaitu pelayanan pembinaan yang bermutu bagi warga binaan. Anak yang telah keluar dari LPA belum tentu menjadi anak yang memiliki perubahan dalam dirinya. Kemungkinan anak untuk melakukan tindak kriminal masih bisa terjadi karena pengaruh kelompok yang sangat kuat. Anak yang telah melakukan tindakan menyimpang maka akan sulit untuk meninggalkan perilaku kriminal apalagi jika ada kesempatan untuk melakukannya kembali. Kadang anak memiliki kecerdasan yang baik akan tetapi tidak bisa menentukan sikap sehingga tindakan menyimpang akan dilakukan. Terdapat juga anak mengetahui akan norma-norma yang berlaku dalam masyarakat, akan tetapi melakukan hal menyimpang karena tidak memiliki kemampuan bersosialisasi yang baik. Keterkaitan antara pikiran, hati dan juga tindakan seharusnya saling terkait, sehingga mampu untuk mengendalikan tindakan menyimpang.

Pentingnya pendidikan kecakapan hidup seiring perubahan jaman, maka muncul pendidikan kecakapan hidup yang memiliki muatan $4-\mathrm{H}$ yaitu head, hand, heart, health (Hendricks, 1998, p.1). Kecakapan head (otak) seringkali juga disebut kemampuan berpikir ilmiah di mana pada dasarnya merupakan pengembangan dari kecakapan berpikir rasional masih bersifat umum. Kecakapan ini sudah lebih mengarah kepada kegiatan yang bersifat akademik/keilmuan. Kecakapan heart (hati) merupakan kecakapan paling utama menentukan seseorang dapat berkembang. Kecakapan hidup yang tergolong dalam aspek ini adalah segala kemampuan yang terkait dengan memahami diri sendiri dan kemampuan berinteraksi dengan lingkungan (sosial). Kecakapan hands (tangan) merupakan kecakapan yang dikaitkan dengan bidang pekerjaan tertentu yang terdapat di masyarakat. Kecakapan health (sehat) merupakan kemampuan untuk mengembangkan hidup sehat (Suryono dkk, 2010, p.12).

Kecakapan hidup 4-H ini belum banyak dikembangkan oleh lembaga ataupun organisasi-organisasi formal maupun non formal. Namun demikian kecakapan hidup $4-\mathrm{H}$ ini mampu memberikan semua kebutuhan seseorang untuk menjadikan pribadi yang baik secara rohani dan jasmani.

Dalam rangka mewujudkan warga binaan yang memiliki keterkaitan kecakapan antara pikiran, hati, tindakan dan gaya hidup sehat, permasalahan-permasalahan yang dihadapi LPA harus dapat dipecahkan seoptimal mungkin agar layanan pembinaan kepada warga binaan menjamin keefektifan pelayanan dan mutu pelayanan serta perubahan sikap pada diri warga binaan. Selain itu, LPA dituntut mampu menghadapi berbagai tantangan internal dan eksternal sebagai kosekuensi dari perubahan-perubahan yang terjadi baik di lingkungan LPA maupun di lingkungan sosial masyarakat. Tantangan internal mencakup peningkatan kualitas kemampuan sumber daya manusia, peningkatan kemandirian dalam pendanaan. Sedangkan tantangan eksternal meliputi perubahan diri warga binaan untuk mampu menghadapi tantangan perkembangan jaman setelah mereka kembali dalam masyarakat. Hal ini dikarenakan mereka adalah usia remaja yang rentan dengan kehidupan luar. Menurut Erikson (Kartono, 1992, p.9) secara umum remaja merupakan usia yang dianggap ada dalam satu periode transisi dengan tingkah laku anti-sosial yang potensial, disertai dengan banyak pergolakan hati atau kekisruhan batin pada fase-fase remaja.

Dengan demikian, dipandang penting untuk melakukan upaya pengembangan LPA terutama dalam hal kecakapan hidup 4-H guna terlaksananya pembinaan yang optimal terhadap warga binaan. Hal ini dapat dilakukan dengan terlebih dahulu melakukan suatu pengkajian yang mendalam terhadap LPA dalam menyelenggarakan kegiatan keterampilan atau kecakapan hidup yang dilakukan sekarang ini. Melalui pengkajian evaluasi diharapkan diperoleh pemahaman mengenai tingkat kemajuan 
dalam penyelenggaraan kecakapan hidup dan memungkinkan dihasilkannya rencanarencana tindakan yang dapat dilakukan guna pengembangan kecakapan hidup di LPA Kutoarjo.

Evaluasi menurut Kaufman \& Thomas (1980, p.4) merupakan proses penentuan kesenjangan antara apa yang terjadi dengan apa yang seharusnya terjadi. Menurut Worthen dan Sanders (Sudjana 2006, p.20) evaluasi adalah suatu proses pengidentifikasian dan mengumpulkan informasi untuk membantu para pengambil keputusan dalam memilih berbagai alternatif.

\section{METODE}

Penelitian ini merupakan penelitian evaluasi yang dilaksanakan di LPA Kelas IIA Kutoarjo. Penelitian dilaksanakan pada bulan September 2012 sampai dengan Februari 2013.

Penelitian ini merupakan penelitian kualitatif dengan subjek penelitian sebanyak 10 anak yang mengikuti kegiatan keterampilan. Tempat penelitian di LPA Kelas IIA Kutoarjo. Pengumpulan data menggunakan wawancara, observasi dan dokumentasi. Analisis data secara kualitatif dengan tahaptahap proses reduksi data, penyajian data dan penarikan kesimpulan. Teknik keabsahan data menggunakan teknik trianggulasi, perpanjangan pengamatan dan meminta pendapat ahli.

\section{HASIL PENELITIAN DAN PEMBAHASAN}

\section{Hasil Penelitian}

Dari hasil wawancara dengan narasumber dan warga belajar dapat diperoleh data bahwa kegiatan keterampilan perkebunan, peternakan dan pembuatan sandal sangat dibutuhkan oleh warga binaan untuk menambah pengalaman dan bekal mereka setelah keluar dari LPA. Hal tersebut dapat dilihat dari respon positif dan partisipasi aktif warga binaan dalam kegiatan keterampilan.

Warga binaan yang mengikuti kegiatan keterampilan tidak memiliki dasar atau basic keterampilan yang ditekuninya. Jadi, mereka tidak memiliki pengalaman sebe- lumnya terkait keterampilan yang dijalaninya sekarang.

Terkait kondisi tanah dan lingkungan sekitar mendukung untuk pelaksanaan kegiatan keterampilan perkebunan dan peternakan. Hal ini dikarenakan tanah di sana bersifat agraris. Terkait keterampilan pembuatan sandal kondisi lingkungan di sana juga mendukung yaitu adanya ruangan dengan fasilitas keterampilan sebagai sarana kegiatan keterampilan.

Motivasi warga belajar dalam mengikuti kegiatan keterampilan sangat tinggi. Hal ini terlihat dari kesiapan mereka mengikuti kegiatan keterampilan dari awal sampai waktu keterampilan selesai. Sealin itu adanya kebebasan dalam memilih keterampilan sehingga warga belajar lebih fokus dengan keterampilan yang diminatinya.

Warga belajar yang mengikuti kegiatan keterampilan memiliki latar belakang pendidikan yang berbeda-beda. Mulai dari paket $A$, paket $B$ dan paket $C$. Namun demikian latar belakang pendidikan tersebut tidak menjadikan hambatan bagi mereka. Hal ini dikarenakan keterampilan-keterampilan yang ada lebih menekankan pada kegiatan praktek langsung, di mana warga belajar lebih mudah untuk mengikutinya.

Narasumber sebagai fasilitator warga belajar dalam hal keterampilan juga memiliki latar belakang pendidikan yang berbeda-beda. Meskipun demikian mereka telah memiliki kemampuan dalam hal keterampilan. Hal ini dikarenakan sebelumnya mereka telah mendapatkan pendidikan dan pelatihan terkait keterampilan

Kurikulum dalam keterampilan perkebunan, peternakan dan pembuatan sandal yaitu praktek secara langsung dengan menggunakan berbagai media dalam keterampilan tersebut. Dalam pelaksanaan kegiatan keterampilan di LPA Kutoarjo, pendanaan berasal dari pusat. Dalam hal ini dana yang diberikan mencukupi untuk kegiatn keterampilan. Keberadaan saranaprasarana yang ada di sana mampu mendukung kegiatan keterampilan.

Aktifitas warga belajar dalam mengikuti kegiatan keterampilan dapat dikatakan baik. Hal ini dapat dilihat dari aktifitas mereka dalam menjalankan tugasnya dengan 
sungguh-sungguh dan penuh hati-hati. Para warga binaan selalu mengikuti kegiatan dengan baik dan tidak pernah bolos. Sikap keingintahuan mereka juga tinggi. Hal ini terlihat dari sikap berani bertanya untuk hal yang belum mereka pahami.

Media pembelajaran yang digunakan dalam kegiatan keterampilan menggunakan bahan dan alat yang digunakan dalam kegiatan keterampilan tersebut dan bersifat langsung. Terkait dengan pengelolaan interaksi belajar mengajar, narasumber selalu mengkondisikan suasana yang akrab. Warga belajar diberi kebebasan untuk bertanya langsung kepada narasumber terkait hal yang belum diketahui. Narasumber tidak membeda-bedakan terhadap warga belajar. Narasumber juga selalu menanyakan terkait kesulitan yang dihadapi.

Hubungan antarpribadi dalam proses kegiatan keterampilan sangat dibutuhkan agar kegiatan dapat berjalan sesuai dengan tujuan. Hubungan yang terjalin antara warga binaan dengan para narasumber di LPA Kutoarjo terjalin dengan baik. Hal ini dapat terlihat dari cara komunikasi mereka yang akrab seperti anggota keluarga sendiri

Hasil penelitian memberikan gambaran pencapaian keberhasilan LPA dalam melakukan pembinaan melalui kegiatan keterampilan bagi warga binaan. Keberhasilan tersebut yaitu perubahan perilaku yang terjadi pada kelompok sasaran atau warga binaan yang mengikuti kegiatan keterampilan perkebunan, peternakan dan pembuatan sandal. Hal ini sesuai dengan tujuan kegiatan keterampilan yaitu agar terjadi perubahan perilaku pada warga binaan yang meliputi kemampuan dalam bersikap dan berpikir. Hasil penelitian menunjukkan bahwa pada kecakapan tangan, kecakapan memberi menunjukkan kategori baik sedangkan pada kecakapan bekerja terdapat kecakapan yang belum mampu dikembangkan dengan baik yaitu pada kemampuan pemasaran. Pada kecakapan hati, kecakapan peduli menunjukkan kategori baik sedangkan pada kecakapan relasi warga belajar belum mampu mengembangkan kecakapan resolusi konflik. Pada kecakapan otak terdapat kemampuan yang belum dikembangkan de- ngan baik yaitu kemampuan berpikir kritis, kemampuan pencatatan, dan kemampuan perencanaan. Pada kecakapan sehat, kecakapan kehidupan menunjukkan kategori baik, sedangkan pada kecakapan kepribadian terdapat kemampuan yang belum mampu dikembangkan yaitu kemampuan kedisiplinan. Meskipun demikian kecakapan yang belum mampu dikembangkan tersebut tidak menjadi penghambat warga belajar dalam merubah perilakunya.

Dalam penyelenggaraan kegiatan program keterampilan tidak semuanya dapat berjalan dengan lancar. Terdapat berbagai kendala dalam pelaksanaannya. Adapaun kendala-kendala tersebut adalah; (a) Kekosongan para petugas, sehingga menyebabkan para petugas memiliki peran ganda yaitu sebagai narasumber dan memegang jabatan dalam organisasi; (b) Sikap kurang disiplin warga belajar dalam memulai kegiatan keterampilan; (c) Kurang optimalnya jalinan kerja sama antara LPA dengan lembaga nonformal lainnya; (d) Kondisi alam yaitu serangan hama dan cuaca yang tidak menentu.

\section{Pembahasan}

Pelaksanaan program kecakapan hidup bagi warga binaan di LPA Kutoarjo memiliki tujuan untuk pelatihan kerja, memberikan bekal keterampilan, pengetahuan, sikap dan kemampuan yang dapat dimanfaatkan untuk usaha mandiri dalam meningkatkan taraf hidupnya setelah kembali dalam masyarakat. Terkait aspek konteks, kebutuhan dan partisipasi warga belajar sangat antusias untuk mengikuti kegiatan keterampilan. Dasar keterampilan yang tidak dimiliki mereka sebelumnya tidak menjadi penghambat proses keterampilan. Begitu juga dengan kondisi alam di sana mendukung untuk kegiatan keterampilan perkebunan dan peternakan.

Pada aspek masukan yang meliputi motivasi warga belajar menunjukkan tinggi, karakteristik warga belajar tidak menghambat proses pembelajaran, karakteristik narasumber mendukung kegiatan keterampilan, kurikulum yang diterapkan dapat diterima dengan mudah oleh warga belajar, 
pendanaan dan sarana prasarana juga mendukung proses pembelajaran.

Dalam proses pembelajaran warga belajar memiliki kesungguhan dalam belajar. Media dan metode yang diterapkan dalam proses pembelajaran yaitu menggunakan berbagai peralatan yang digunakan sebagai penunjang kegiatan. Hal ini dikarenakan tidak adanya kurikulum yang terstruktur, hanya menerapkan praktek langsung. Strategi pembelajaran seperti ini dapat diterima lebih mudah oleh warga belajar dibanding dengan pemberian materi teori terlebih dahulu. Selain itu hubungan yang terjalin antara narasumber dengan warga belajar sangat dekat seperti hubungan dalam keluarga. Hal ini membuat warga belajar merasa nyaman dalam mengikuti kegiatan pembelajaran.

Penelitian evaluasi tentang kecakapan hidup ini tidak hanya memfokuskan pada kemampuan vokasional warga belajar setelah mereka mengikuti kegiatan keterampilan melainkan juga untuk mengetahui dampak kecakapan nonvokasional yang dimiliki oleh warga belajar setelah mengikuti keterampilan. Hal ini didasarkan pada kecakapan hidup tidak hanya diorientasikan pada kecakapan yang dibutuhkan dalam peningkatan kualitas ekonomi atau kecakapan untuk melakukan tugas atau peran yang tidak langsung berhubungan dengan peningkatan aspek ekonomi. Model kecakapan hidup yang dimaksud yaitu kecakapan hidup 4-H (Head, Hand, Heart, and Health). Model ini mengadopsi pemikiran kecakapan hidup yang telah dikembangkan di Ohio, Amerika Serikat.

Program rehabilitasi LPA bagi warga binaan dapat diwujudkan melalui program kecakapan hidup. Pada konteks pencegahan yaitu dengan adanya program kecakapan hidup maka warga belajar memiliki perilaku positif dan dapat mencegah perilaku yang negatif. Pada aspek perlindungan, program kecakapan hidup mampu memberikan perubahan psikologis yaitu dengan cara pendampingan yang dilakukan secara terusmenerus. Pada aspek pelayanan, program kecakapan hidup mampu menumbuhkan sikap atau perilaku positif warga belajar yaitu dengan adanya pelayanan yang baik dari semua stekholder yang ada di LPA. Pada aspek pengasuhan, program kecakapan hidup mampu menjadikan warga belajar merasa nyaman menjalani tahanan karena suasana di LPA bernuansa kekeluargaan.

Dalam kegiatan keterampilan perkebunan, peternakan dan pembuatan sandal, masing-masing memiliki tingkat perbedaan muatan kecakapan hidup. Muatan kecakapan hidup ini merupakan dampak dari adanya kegiatan keterampilan bagi warga belajar. Meskipun demikian dalam pelaksanaan program kecakapan hidup, model kecakapan hidup 4-H tidak direncanakan secara tersirat. Muatan kecakapan hidup yang ada merupakan hasil dari penelitian

Keberhasilan program kecakapan hidup bagi warga binaan dapat terlihat dari adanya perubahan perilaku. Meskipun tidak semua muatan kecakapan hidup 4-H mampu dimiliki oleh warga binaan, akan tetapi kecakapan yang telah dimiliki dapat digunakan sebagai bekal dalam menjalani kehidupannya di masyarakat. Hal ini dikarenakan kecakapan hidup tidak hanya diorientasikan dalam hal peningkatan kualitas ekonomi atau kecakapan untuk melakukan tugas atau peran yang tidak langsung berhubungan dengan peningkatan aspek ekonomi.

Kecakapan hidup yang masih kurang dikembangkan oleh warga binaan dikarenakan dalam kegiatan keterampilan warga belajar kurang diberikan kemampuan kecakapan tersebut. Sedangkan kecakapan hidup yang dapat dikembangkan dengan baik mampu menjadikan dasar warga belajar untuk bersikap dalam masyarakat. Sebagai contoh dalam hal kecakapan tangan warga belajar mampu menjalankan kehidupan yang berkaitan dengan pekerjaan yang sesuai dengan dirinya. Dengan demikian mereka mampu bertahan hidup dan melanjutkan kehidupannya.

Kendala-kendala yang memengaruhi keberhasilan program keterampilan yaitu kurang kedisiplinan warga belajar. Sikap kurang disiplin warga belajar terjadi ketika mereka mulai masuk kegiatan keterampilan. Hal ini dikarenakan mereka membutuhkan waktu yang lama untuk sarapan pagi. Namun demikian sikap kurang disiplin tersebut tidak mempengaruhi kesungguhan 
mereka dalam mengikuti kegiatan keterampilan kerja. Kekosongan narasumber juga menjadi kendala dalam proses pembelajaran akan tetapi para petugas yang ada mampu menjadi narasumber program keterampilan dengan baik. Kendala selanjutnya adalah kurang optimalnya jalinan kerja sama antara LPA Kutoarjo dengan lembaga nonformal lainnya. Kerja sama yang selama ini dijalin hanya berlangsung pada awal program. Namun demikian hal ini tidak mengurangi motivasi warga belajar. Kegiatan program tetap berjalan dengan baik. Kendala yang terakhir adalah konsidi alam yang tidak menentu. Cuaca yang buruk seperti kurang air saat musim kemarau dan hujan akan memengaruhi pertumbuhan tanaman. Akan tetapi hal tersebut tidak sering terjadi, hanya kadang-kadang saja.

Kendala kekosongan narasumber dapat diatasi dengan penambahan narasumber. Akan tetapi hal ini menjadi urusan dari pusat Kemenkumham yang menangani perekrutan pegawai. Hal yang bisa dilakukan yaitu mendatangkan narasumber dari luar. Hal ini tentu saja menjadi pertimbangan karena harus menambah anggaran dana. Oleh karena itu untuk mengatasi permasalahan tersebut, yang bisa dilakuakn LPA adalah memberikan tugas ganda bagi para pegawai sekaligus sebagai para instruktur.

Terkait kedisiplinan warga belajar dapat diterapkan kebiasaan disiplin. Hal ini dapat dimulai dari kedisiplinan para narasumber sebagai contoh kepada warga belajar. Pentingnya sikap disiplin bagi warga belajar yaitu agar setelah mereka kembali ke masyarakat dan memiliki pekerjaan, bisa memanfaatkan waktu dengan sebaik-baiknya sehingga tidak ada waktu yang sia-sia. Penggunaan waktu yang tidak efektif bagi warga belajar nantinya dikhawatirkan mereka akan kembali ke dalam kehidupan yang tidak positif lagi.

Bentuk kerja sama yang dilakukan dengan lembaga non formal seperti SKB, dimaksudkan untuk memperluas jaringan kemitraan. Akan tetapi kenyataan yang terjadi kerja sama tidak berlangsung sampai akhir program. Misalnya, pada program peternakan ayam, penyuluhan tentang ternak hanya diberikan pada awal saja dan selanjutnya tidak pernah lagi ada kunjungan atau komunikasi yang pada akhirnya pihak LPA harus bisa mendiri dalam pelaksanaannya. Pada keterampilan perkebunan tidak ada kerja sama yang dijalin. Hal ini karena para pegawai memiliki pengalaman dalam hal tersebut. Akan tetapi dalam hal ini kegiatan keterampilan perkebunan kurang informasi dalam hal kemajuan dan perkembangan keterampilan tersebut.

\section{SIMPULAN DAN SARAN}

\section{Simpulan}

Pelaksanaan program kecakapan hidup yang meliputi aspek konteks, masukan, proses, dan hasil di LPA Kutoarjo dapat berjalan dengan baik dan sesuai dengan tujuan program kecakapan hidup.

Keberhasilan program keterampilan dapat dilihat dari perubahan perilaku warga belajar yang ditunjukkan pada perubahan kecakapan tangan, kecakapan hati, kecakapan otak dan kecakapan sehat. Dari kecakapan-kecakapan tersebut dapat disimpulkan bahwa kecakapan tersebut menunjukkan baik.

Dalam pelaksanaan kegiatan keterampilan tidak terlepas dari kendala-kendala. Akan tetapi kendala yang ada dapat teratasi dengan baik sehingga kegiatan keterampilan dapat berjalan dengan baik pula. Kendala tersebut meliputi kekosongan para narasumber, ketidakdisiplinan warga belajar dalam memulai kegiatan keterampilan, kerja sama yang kurang optimal dan keadaan alam yang tidak menentu.

\section{Saran}

Peningkatan budaya disiplin baik terhadap warga belajar maupun para petugas dan narasumber. Perlunya perluasan jaringan kerja sama yang bersifat saling menguntungkan dan berkelanjutan. Penambahan narasumber dengan cara mendatangkan dari lembaga lain.

\section{DAFTAR PUSTAKA}

Anwar. (2006). Pendidikan kecakapan hidup (Life skills education). Bandung: Alfabeta 
Depdiknas. (1995). Undang-Undang No. 12 Tahun 1995, tentang pemasyarakatan

Francis, M. (2007). Life skills education. Diakses dari www.changingminds.org pada tanggal 22 September 2012.

Hendricks, P. (1998). "Developing youth curriculum using the targeting Life Skills Model” dalam www.extension.edu/4-H.com.

Izzaty, Rita Eka, dkk. (2008). Perkembangan peserta didik. Yogyakarta: UNY Press.

Kamil, Mustofa. (2010). Model pendidikan dan pelatihan (Konsep dan aplikasi). Bandung :Alfabeta.

Kartono, Kartini. (1992). Patologi Sosial 2. Jakarta: Rajawali Pers.
Kaufman, Roger \& Thomas, Susan. (1980). Evaluation without fear. New York: New Viewpoints.

Sudjana, Djudju. (2006). Evaluasi program pendidikan nonformal. Bandung: PT Remaja Rosdakarya.

Suryono, Yoyon, dkk. (2010). Pendidikan nonformal dan pengurangan kemiskinan di pedesaan (pendekatan pengembangan model program pendidikan kecakapan hidup) di Provinsi Daerah Istimewa Yogyakarta, Laporan Hibah Kompetensi pada tahun 2010, tidak diterbitkan, Lembaga Penelitian Universitas Negeri Yogyakarta, Yogyakarta.

Worthen, B \& Sanders, James. (1973). Educational evaluation:theory and practice. Worthington: Jones Publishing Company. 